\title{
Correction to: Ethnobotanical characterization of medicinal plants used in Kisantu and Mbanza-Ngungu territories, Kongo-Central Province in DR Congo
}

Kibungu Kembelo Pathy ${ }^{1,2^{*}}$, Nzuki Bakwaye Flavien ${ }^{1}$, Belesi Katula Honoré ${ }^{1}$, Wouter Vanhove ${ }^{2}$ and Patrick Van Damme 2,3

Correction to: J Ethnobiology Ethnomedicine 17, 5 (2021) https://doi.org/10.1186/s13002-020-00428-7

Following publication of the original article [1], it came to the attention of the journal that the fifth author's name had been miswritten as 'Van Damme Patrick'; the name should be written as 'Patrick Van Damme'.

The name has been corrected in the published article and the corrected name may be found in this correction article, too.

\begin{abstract}
Author details
'Department of Environmental Sciences, Kinshasa University (UNIKIN), Kinshasa, XIBP 127Democratic Republic of the Congo. ${ }^{2}$ Laboratory of Tropical and Subtropical Agriculture and Ethnobotany, Ghent University, Coupure Links 653, B-9000 Ghent, Belgium. ${ }^{3}$ Faculty of Tropical AgriSciences, Czech University of Life Sciences Prague, Kamycka 129, Prague 6 - Suchdol, 16521 Prague, Czech Republic.
\end{abstract}

Published online: 05 February 2021

\section{Reference}

1. Pathy KK, Flavien NB, Honoré BK, et al. Ethnobotanical characterization of medicinal plants used in Kisantu and Mbanza-Ngungu territories, KongoCentral Province in DR Congo. J Ethnobiology Ethnomedicine. 2021;17:5 https://doi.org/10.1186/s13002-020-00428-7.

The original article can be found online at https://doi.org/10.1186/s13002020-00428-7.

* Correspondence: pathy_kibungu@yahoo.fr

'Department of Environmental Sciences, Kinshasa University (UNIKIN), Kinshasa, XIBP 127Democratic Republic of the Congo

${ }^{2}$ Laboratory of Tropical and Subtropical Agriculture and Ethnobotany, Ghent University, Coupure Links 653, B-9000 Ghent, Belgium

Full list of author information is available at the end of the article

(c) The Author(s). 2021 Open Access This article is licensed under a Creative Commons Attribution 4.0 International License, which permits use, sharing, adaptation, distribution and reproduction in any medium or format, as long as you give appropriate credit to the original author(s) and the source, provide a link to the Creative Commons licence, and indicate if changes were made. The images or other third party material in this article are included in the article's Creative Commons licence, unless indicated otherwise in a credit line to the material. If material is not included in the article's Creative Commons licence and your intended use is not permitted by statutory regulation or exceeds the permitted use, you will need to obtain permission directly from the copyright holder. To view a copy of this licence, visit http://creativecommons.org/licenses/by/4.0/ The Creative Commons Public Domain Dedication waiver (http://creativecommons.org/publicdomain/zero/1.0/) applies to the data made available in this article, unless otherwise stated in a credit line to the data. 